[Agr. Biol. Chem., Vol. 32, No. 4, p. 518 521, 1968]

\title{
Study on the Optical Rotatory Dispersion of Di-Peptides and its Application to the Recognition of Di-Peptides from Higher Peptides and Amino Acids
}

\author{
By Hiroshi Meguro, Toshio Konno, Hiroyuki Shiraishi, Eisuke Munekata \\ and Katura Tujimura \\ Department of Food Chemistry, Faculty of Agriculture, \\ Tohoku University, Kita-6-Bancho Sendai \\ Received September 20, 1967
}

Much works on optical rotatory dispersion (ORD) of peptides have been accumulated to elucidate helical conformation in proteins." Recently Beacham et al. ${ }^{2 \prime}$ reported ORD of a series of diastereomers of tri- and tetra-peptides of alanine and serine and calculated the contribution of each chromophore to the molecular rotation.

In this paper use of ORD to differenciate di-peptides of L-amino acids from higher peptides and free amino acids of L-series is described. Hereafter peptides and amino acids of $L_{\text {-series }}$ are written as peptides and amino acids without a term of 'L-series.' The ORD of twenty-four di-peptides, including alanine, valine, leucine, isoleucine, phenylalanine, tyrosine, glutamic acid, asparatic acid and lysine were measured. They were mainly prepared by mixed anhydride method $^{3 \prime}$ by a condensation of $\mathrm{N}$-carbobenzoxyl amino acids ${ }^{41}$ with benzyl esters of amino acids $^{\bar{j}}$ and the

1) E. R. Blout in C. Djerassi, "Optical Rotatory Dispersion,' Mc Graw-Hill, New York, 1960, p. 238; M. Goodman, F. Boardman and I. Listowsky, $J . A m$. Chem. Soc., 85, 2491 (1963) and preceding papers.

2) J. Beacham, V.T. Ivanov, P. M. Scopes and D. R. Sparrow, J. Chem. Soc., 1966 (C) 1449; P. M. Scopes, D. R. Sparrow, J. Beacham and V. T. Wanov, Tetrahedron Letters, 7, 665 (1966).

3) J. R. Vaughan, R. Osato, J. Am. Chem. Soc., 74, 676 (1952).

4) M. Bergmann and L. Zervas, Chem. Ber., 65 $1192(1932)$. protecting groups were removed by catalytic hydrogenation. Secondary functional groups such as $(t)$-amino group of $\mathrm{N}$-terminal lysine were also protected with $\mathrm{N}$-carbobenzoxyl group, ${ }^{4}$-carboxyl group of C-terminal and $\mathrm{N}$-terminal glutamic acids $s^{5,6}$ and that of $\mathrm{C}$ terminal asparatic $\operatorname{acid}^{51}$ with benzyl esters and the phenolic hydroxyl group of C-terminal tyrosine with benzyl ether. ${ }^{7}$ The optical purity of each compound was checked by measurements of specific rotation in water or in diluted hydrochloric acid solutions.

The ORD were measured in the 210 400 $\mathrm{m} \mu$ with a Japan Spectroscopic Model ORD/ UV -5 recording polarimeter at room temperature by use of a quartz cell with an optical path of $1.0 \mathrm{~cm}$. The concentrations of the peptides were $0.1 \%$ in $0.1 \mathrm{~N}$ potassium hydroxide solution or in $0.1 \mathrm{~N}$ hydrochloric acid solution. In order to avoid racemization especially in alkaline solution, all the solutions were prepared just before the measurements.

5) J. P. Greenstein and M. Winitz, "Chem. of Amino acids" Vol. 2, Wiley \& Sons Inc., 196I, p. 923; N. Izumiya, et al., Nippon Kagaku Kaishi, 78, 662 (1957); L. Zervas, M. Winitz and J. P. Greenstein, J. Org. Chem., 22, 1515 (1957).

6) J. P. Greenstein and M. Winitz, "Chem. of Amino acids" Vol. 2, Wiley \& Sons Inc., 1961, p. 943.

7) E. Wunsch, G. Fries and A. Zwick, Chem. Ber., 91, 542 (1958); R. Schwyzer and W. Rittel, Helw. Chim. Acta, 41, 159 (1961). 
Figure 1 shows ORD curves of valyl valine Cotton effect curve with a trough at almost as a typical example of di-peptides which gave a positive single Cotton effect curve with a peak at $225 \mathrm{~m} \mu$ in acid and a negative single

the same wave length in alkali. For comparison, those of valine are shown in Fig. 1.

Table I. Molecular Rotations of Peptides and Amino acids at EXTREMA IN ACID AND ALKALI

Name of compound

Molecular rotation at extrema near $225 \mathrm{~m} \mu$

\begin{tabular}{|c|c|c|c|c|c|c|c|c|}
\hline & $\begin{array}{c}\text { Wave } \\
\text { length } \\
\mathrm{m} \mu\end{array}$ & {$[\mathrm{M}] \times 10^{-2}$} & $\begin{array}{c}\text { Wave } \\
\text { length } \\
\mathrm{m} \mu\end{array}$ & {$[M] \times 10^{-2}$} & Conc. & Solvent & $\underset{{ }^{C} \mathrm{C}}{\mathrm{Temp}}$. & {$[\alpha]_{\mathrm{D}}$} \\
\hline \multicolumn{9}{|l|}{ Di-peptides } \\
\hline $\mathrm{H}$ Ala-Ala $\mathrm{OH}$ & $227(\max )$ & +18 & $227(s)$ & -44 & $20^{\circ}$ & $0.5 \mathrm{~N} \mathrm{HCl}$ & 23 & $-37.5^{\circ}$ \\
\hline $\mathrm{H}$ Val-Val OH & $224(\max )$ & +53 & $226(\min )$ & -32 & $2 \%$ & $\mathrm{H}_{2} \mathrm{O}$ & 17 & $+8.0^{\circ}$ \\
\hline H Glu-Val $\mathrm{OH}$ & $225(\max )$ & +58 & $226(\min )$ & -54 & $2.65 \%$ & $5 \mathrm{~N} \mathrm{HCl}$ & 15 & $+24.5^{\circ}$ \\
\hline H Lys-Val OH & $225(\max )$ & +47 & $224(\min )$ & -42 & 20 & $\mathrm{H}_{2} \mathrm{O}$ & 14 & $+5.0^{\circ}$ \\
\hline H Ala-Leu $\mathrm{OH}$ & $226(\max )$ & +47 & $227(\mathrm{~s})$ & -51 & $50^{\circ}$ & $\mathrm{H}_{2} \mathrm{O}$ & 23 & $-16.8^{\circ}$ \\
\hline H Val-Leu OH & $222(\max )$ & +50 & $223(s)$ & -39 & 109 & $0.1 \mathrm{~N} \mathrm{HCl}$ & 17 & $+6.0^{\circ}$ \\
\hline H Glu-Leu OH & $225(\max )$ & +64 & $224(\min )$ & -38 & $1.8 \%$ & $5 \mathrm{~N} \mathrm{HCl}$ & 14 & $+8.6^{\circ}$ \\
\hline H Lys-Heu OH & $226(\max )$ & +49 & $227(s)$ & -22 & 20 & $\mathrm{H}_{2} \mathrm{O}$ & 16 & $+7.0^{\circ}$ \\
\hline H Val-Ileu OH & $225(\max )$ & +53 & $225(\max )$ & +18 & $7.5 \%$ & $0.1 \mathrm{~N} \mathrm{HCl}$ & 17 & $+8.1^{\circ}$ \\
\hline H Glu-Ileu OH & $225(\max )$ & +55 & $226(\min )$ & -45 & 206 & $5 \mathrm{~N} \mathrm{HCl}$ & 13 & $+33.0^{\circ}$ \\
\hline H Lys-Ileu OH & $226(\max )$ & +53 & $226(\min )$ & -38 & $2 \%$ & $\mathrm{H}_{2} \mathrm{O}$ & 15 & $+7.5^{\circ}$ \\
\hline H Ala-Asp OH & $224(\max )$ & +18 & $220(\mathrm{~min})$ & -35 & 290 & $0.5 \mathrm{~N} \mathrm{HCl}$ & 23 & $+3.5^{\circ}$ \\
\hline $\mathrm{H}$ Val-Asp $\mathrm{OH}$ & $221(\max )$ & +46 & $225(\min )$ & -4.6 & $2 \%$ & $\mathrm{H}_{2} \mathrm{O}$ & 17 & $+25.0^{\circ}$ \\
\hline H Glu-Asp OH & $222(\max )$ & +29 & $226(s)$ & -16 & $1.05 \%$ & $\mathrm{H}_{2} \mathrm{O}$ & 15 & $+29.4^{\circ}$ \\
\hline H Lys-Asp OH & $224(\max )$ & +26 & $227(s)$ & -10 & $1.3 \%$ & $\mathrm{H}_{2} \mathrm{O}$ & 15 & $+20.8^{\circ}$ \\
\hline H Val-Glu OH & $223(\max )$ & +27 & $225(\mathrm{~min})$ & -1.5 & $1.5 \%$ & $\mathrm{H}_{2} \mathrm{O}$ & 17 & $+4.6^{\circ}$ \\
\hline H Glu-Glu OH & $227(\max )$ & +61 & $225(\min )$ & -15 & 20 & $5 \mathrm{~N} \mathrm{HCl}$ & 14 & $+18.0^{\circ}$ \\
\hline H Lys-Glu $\mathrm{OH}$ & $226(\max )$ & +51 & $227(\mathrm{~s})$ & -8 & $3.1 \%$ & $\mathrm{H}_{2} \mathrm{O}$ & 17 & $+19.0^{\circ}$ \\
\hline H Ala-Phe OH & $227(s)$ & +119 & $227(\mathrm{~s})$ & +34 & $2 \%$ & $\mathrm{H}_{2} \mathrm{O}$ & 23 & $+37.5^{\circ}$ \\
\hline H Val-Phe OH & $223(\max )$ & +108 & $224(\mathrm{~min})$ & -17 & $20_{0}$ & $\mathrm{H}_{2} \mathrm{O}$ & 17 & +46.0 \\
\hline H Glu-Phe OH & $224(\max )$ & +135 & $225(\max )$ & +63 & $10_{0}$ & $5 \mathrm{~N} \mathrm{HCl}$ & 15 & $+24.0^{\circ}$ \\
\hline H Lys-Phe OH & $227(\max )$ & +89 & $227(s)$ & +48 & 20 & $\mathrm{H}_{2} \mathrm{O}$ & 16 & $+16.5=$ \\
\hline $\mathrm{H}$ Val-Tyr OH & $225(\max )$ & +81 & $225(\max )$ & +20 & 20 & $2.5 \mathrm{~N} \mathrm{HCl}$ & 17 & $+33.0^{\circ}$ \\
\hline $\mathrm{H}$ Glu-Tyr OH & $225(\max )$ & +26 & $220(\max )$ & +13 & $2 \%$ & $5 \mathrm{~N} \mathrm{HCl}$ & 17 & $+30.0^{\circ}$ \\
\hline Tri-peptides* & & & & & & & & \\
\hline $\begin{array}{l}\text { H Ala-Ala-Ala OH } \\
\text { Tetra-peptides* }\end{array}$ & $227(s)$ & -4 & $227(s)$ & -62 & - & & - & - \\
\hline $\mathrm{H}$ Ala-Ala-Ala-Ala OH & $227(s)$ & -45 & $227(\mathrm{~s})$ & -93 & - & & - & - \\
\hline Amino acids & & & & & & & & \\
\hline Alanine & $226(\max )$ & +7.3 & $224(\max )$ & +2.4 & - & & - & - \\
\hline Leucine & $226(\max )$ & +14 & $225(\max )$ & +8.3 & - & & - & - \\
\hline Phenylalanine & $225(\max )$ & +25 & $226(\max )$ & +16.1 & - & & - & - \\
\hline Valine & $224(\max )$ & +18 & $222(\max )$ & +6.9 & - & & - & - \\
\hline Glutamic acid & $224(\max )$ & +17 & $225(\mathrm{~s})$ & +7.5 & - & & - & - \\
\hline Lysine & $220(\max )$ & +17 & $225(s)$ & +9.3 & - & & - & - \\
\hline
\end{tabular}

* Tri- and tetra-peptides of L-alanine were not measured but referred from the value of Beacham $t$ t al.21 $(\max ),(\min )$ and $(\mathrm{s})$ mean peak, minimum and the shortest wave length at which signal noise ratio reached about $10 \%$ respectively. 


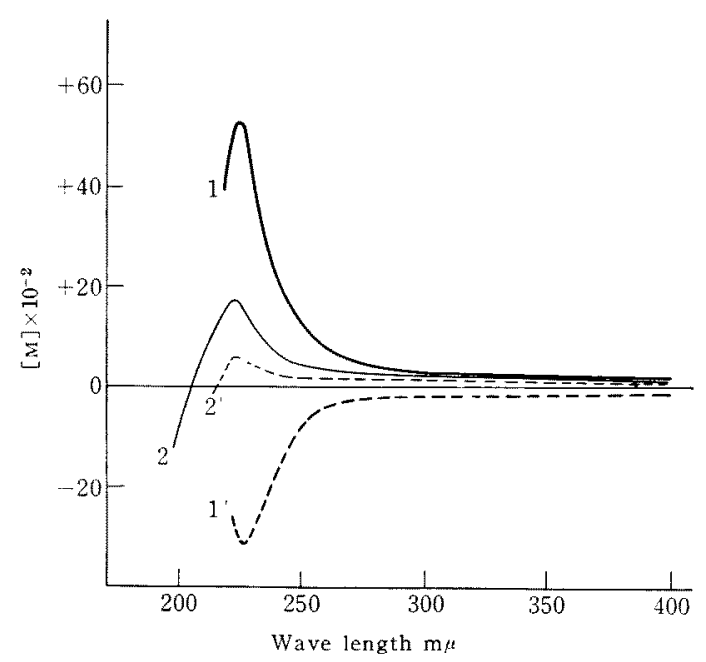

FIG. 1. Optical Rotatory Dispersion Curves of Valyl Valine and Valine of L-Series in Acid and in Alkali.

$$
\begin{aligned}
& \text { - } 1 \text { Valyl-valine in } 0.1 \mathrm{~N} \mathrm{HCl} \\
& \text {..... 1' " in } 0.1 \mathrm{~N} \mathrm{KOH} \\
& 2 \text { Valine in } 0.1 \mathrm{~N} \mathrm{HCl} \\
& \text {-.... } 2^{\prime} " \text { in } 0.1 \mathrm{~N} \mathrm{KOH}
\end{aligned}
$$

measured in the same manner as those of dipeptides and they all gave positive single Cotton effect curves with a peak at about $225 \mathrm{~m} \mu$ both in acid and in alkali as well as valine although the peaks in acid were higher than those in alkali.

Table I shows the molecular rotations of amino acids and di-peptides at the extreme about $225 \mathrm{~m} \mu$ in acid and in alkali. Measurements within $10 \%$ of signal noise ratio could be made until at about $220 \mathrm{~m} \mu$ in acid, and the experimental errors were about $5 \sim 10 \%$ at $225 \mathrm{~m} \mu$. However, in alkali the reproducibilities were slightly worse than in acid, and

In acid<smiles>[R]C(N)C(=O)NC([R])C(=O)O</smiles>

$\alpha$-Protonated amino amide and Carboxyl. the signal noise ratios in some compounds were more than $10 \%$ at $225 \mathrm{~m} \mu$. In such cases, the molecular rotations at the shortest wave length at which signal noise ratio reached about $10 \%$ were measured instead of those at the extrema and the values were enough to determine the signs of the first extreme.

Di-peptides are amphoteric compounds containing chromophores of at least one amino group at $\mathrm{N}$-terminal, one amide group between two asymmetric carbons and one carboxyl group at C-terminal.

In acid, amino groups are protonated and the carboxyl and amide groups remain nonionized. On the other hand, alkali carboxyl groups are ionized to carobxylate and amino and amide groups remain nonionized. If the total ORD of oligopeptide is the sum of the contributions of the chromophores in the molecule, the first extremum of a dipeptide at $225 \mathrm{~m} \mu$ is considered as a superposition of the first extrema of the Cotton effects of the chromophores which have the absorption maximum at the wave length region slightly shorter than $225 \mathrm{~m} \mu$ and in this case they are carbonyl groups than amino or protonated amino groups which have absorption maxima at shorter wave length than those of carbonyl groups. When di-peptides do not contain other chromophores such as valyl leucine the change of the sign of extrema in acid and in alkali mean that the sum of the contributions of carbonyl chromophores in $\alpha$-(protonated amino)-amide groups and C-terminal carboxyl group in acid is positive but the sum of the contributions of carbonyl chromophores in $\alpha$ (amino)-amide group and C-terminal carboxylate in alkali is negative.

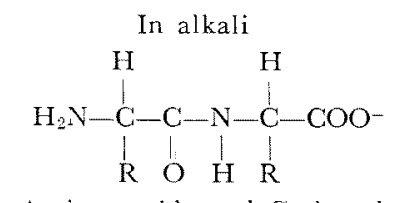

$\alpha$-Amino amide and Carboxylate.

FIG. 2. The Forms of Carbonyl Chromophores of Dipeptides in Acid and in Alkaline Solution 
When di-peptides contain other chromophores such as lysine, glutamic acid, asparatic acid, phenylalanine and tyrosine, the contributions of the additional chromophores should be counted. However, it is important that most of the di-peptides with other chromophores gave the same tendency of the change of sign in the similar measurements as shown in Table I. It should be also noted that although some di-peptides which have aromatic amino acid at $\mathrm{C}$-terminal gave a weak positive extrema in alkaline solution as exceptions, they also gave considerable decrease of positive optical rotation in alkali. The discrepancies of valyl isoleucine needs further research.

The decrease of the positive molecular rotations of amino acids at the extrema around $225 \mathrm{~m} \mu$ in alkali may suggest that the positive contribution of $\alpha$-(protonated amino) carboxyl chromophore in acid is more positive than that of $\alpha$-amino carboxylate in alkali.

On the contributions of various chromophores of tri- and tetra-peptides of $\mathrm{L}$-alanine at $227 \mathrm{~m} \mu$, Beacham ${ }^{2}$ showed that central amide which does not have terminal free amino at $\alpha$-position gave a negative contribution independent of $\mathrm{pH}$.

Although their quantitative data are limited in alanyl and seryl peptides, it can be expected that other tri-peptides or at least oligopeptides of higher than tri-peptides would give negative optical rotation both in acid and in alkali because of the increase of the number of negative contributing central amides, or the sum of the amide contributions would be negative enough to cancel the positive contribtioun due to terminal chromophores even in acid as well as in alkali.

It is also supported by the fact that all the natural proteins and synthetic polypeptides gave negative optical rotations at $225 \mathrm{~m} \mu$ so long as they are in random state.

Although it is necessary to study the con- tributions of chromophores in other amino acids, a possibility of application of ORD is proposed to differenciate di-peptides from higher oligopeptides and amino acids by measuring their optical rotations near at about $225 \mathrm{~m} \mu$ in acid and in alkali, based on a hypothesis that the molecular rotations of oligopeptides at the wave length are the sum of the negative contributing central amides which is independent on $\mathrm{pH}$ and C-terminal carboxyl and $\mathrm{N}$-terminal amide chromophores which are dependent on $\mathrm{pH}$.

When a compound is identified by other methods as an amino acid or an oligopeptide of L-series and it gives positive optical rotations at $225 \mathrm{~m} \mu$ both in acid and in alkali, it is most probable an amino acid. When it gives a positive optical rotation in acid and a negative one in alkali, it is highly probable to be a di-peptide or in few cases a tripeptide. When it gives negative optical rotations both in acid and in alkali, it is considered to be larger than a tri-peptide.

In this paper no compound of $\mathrm{D}$-series was studied. However, if oligopeptides are composed only of D-amino acids, their ORD curves should be symmetrical with the zero line against their enatiomorphs. Therefore the method may possibly be applied to Dseries only be changing the signs of the optical rotations of $\mathrm{L}$-series.

When a oligopeptide is composed of mixed D- and L-amino acids or of glycine, this method can not be applied.

The measurement of circular dichromism of the same condition will be used for the qualitative determination of the positive or negative sign of their optical rotations.

Acknowledgement. We thank Ajinomoto Company for the gift of amino acids and Mr. Tateo Suzuki and Tsuneo Kamata for the preparation of alanyl and valyl di-peptides. 